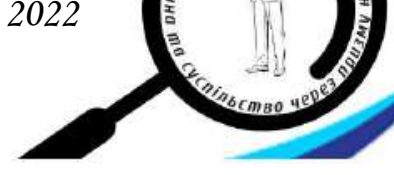

УДК 343.57 (477)

https://doi.org/10.52058/2786-5274-2022-1(3)-301-310

Одинцова Олена Володимирівна кандидат юридичних наук, доцент кафедри кримінально-правових дисциплін, Луганський державний університет внутрішніх справ імені Е.О. Дідоренка, вул. Донецька, 1, м. Сєвєродонецьк, 93401, тел.: (050) 14-35-064, https://orcid.org/0000-0003-3864-228X

\title{
МЕЖІ КРИМІНАЛЬНО-ПРАВОВОГО РЕАГУВАННЯ НА НЕЗАКОННИЙ ОБІГ НАРКОТИЧНИХ ЗАСОБІВ ТА ПСИХОТРОПНИХ РЕЧОВИН У НЕВЕЛИКИХ РОЗМІРАХ
}

Анотація. Статтю присвячено проблемі криміналізації незаконного виробництва, виготовлення, придбання та зберігання наркотичних засобів чи психотропних речовин у невеликих розмірах без мети передачі, оскільки у проєкті нового Кримінального кодексу України запроваджено відповідну кримінально-правову заборону. Аналіз підстави та соціальних і соціальнопсихологічних принципів криміналізації діянь дозволяє дійти висновку, що у сучасних умовах криміналізація зазначених дій $\epsilon$ недоцільною. Вони $\epsilon$ найменш суспільно небезпечними у порівнянні із аналогічними діями 3 наркотичними засобами та психотропними речовинами 3 метою збуту (передачі) або без мети збуту (передачі) у розмірах, передбачених чинною статтею 309 КК України. Занадто велика поширеність наркоманії робить нереальним притягнення до кримінальної відповідальності переважної більшості осіб, які виготовляють (виробляють), придбають, зберігають вказані засоби та речовини у невеликих розмірах. Криміналізація цих дій може негативно вплинути на авторитет держави, оскільки нормою стане безкарність дій, оголошених кримінально протиправними. Цей крок також може посилити наявну тенденцію протидії наркозлочинності, зміст якої полягає у тому, що у сфері впливу з боку правоохоронних органів знаходяться переважно найменш суспільно небезпечні прояви цього виду кримінально протиправної діяльності.

Пропонується залишити незаконне виробництво, виготовлення, придбання та зберігання наркотичних засобів чи психотропних речовин у невеликих розмірах без мети передачі адміністративними правопорушеннями. Ефективність протидії наркоманії та наркозлочинності має бути підвищена за рахунок не посилення репресивних заходів щодо споживачів наркотиків та психотропних речовин, а вдосконалення профілактичної роботи зі споживачами, групами ризику, послаблення чинників наркоманії.

Ключові слова: криміналізація діянь, підстава криміналізації, принципи криміналізації, незаконний обіг наркотиків та психотропних речовин, 
наркотичні засоби у невеликих розмірах, психотропні речовини у невеликих розмірах.

Odintsova Olena Volodymyrivna Candidate of Law, Associate Professor of the Department of Criminal Law disciplines, Luhansk State University of Internal Affairs named after E.O. Didorenko, Donetska St., 1, Severodonetsk, 93401, tel.: (050) 14-35-064, https://orcid.org/0000-0003-3864-228X

\title{
THE LIMITS OF CRIMINAL RESPONSE ON ILLEGAL TRAFFICKING OF NARCOTIC DRUGS AND PSYCHOTROPIC SUBSTANCES IN SMALL QUANTITIES
}

\begin{abstract}
The article is devoted to the problem of criminalization of illegal production, manufacture, acquisition and storage of narcotic drugs or psychotropic substances in small quantities without the purpose of transfer, since the draft of the new Criminal Code of Ukraine introduced a corresponding criminal law prohibition. An analysis of the foundations and social and socio-psychological principles of the criminalization of acts allows us to conclude that in modern conditions the criminalization of these actions is inappropriate. They are less socially dangerous in comparison with similar actions with narcotic drugs and psychotropic substances, committed for the purpose of selling (transfer) or without the purpose of marketing (transfer), but in the amount provided for by the current article 309 of the Criminal Code of Ukraine. Too high prevalence of drug addiction makes it unrealistic to prosecute the overwhelming majority of persons who manufacture (produce), acquire, store these drugs and substances in small quantities. The criminalization of these actions can negatively affect the authority of the state, since impunity for actions declared criminal will become the norm. The analysis of criminal statistics allows us to assert that today the following trend has emerged in combating crime in the sphere of illegal drug trafficking. In the sphere of influence of law enforcement agencies are mainly the least socially dangerous manifestations of this type of crime. Criminalization of the specified actions with narcotic drugs and psychotropic substances on a small quantities may strengthen the current trend.

It is proposed to leave illegal production, manufacture, acquisition and storage of narcotic drugs or psychotropic substances in small quantities without the purpose of selling (transferring) by administrative offenses. The effectiveness of counteracting drug addiction and crime in the sphere of illegal drug trafficking should be increased by not strengthening repressive measures against drug users and psychotropic substances, but by improving preventive work with their users, risk groups, and weakening drug addiction factors.
\end{abstract}

Keywords: criminalization of acts, grounds for criminalization, principles of criminalization, illegal drug trafficking, drugs in small quantities, psychotropic substances in small quantities. 


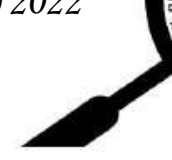

Постановка проблеми. У минулому столітті стан розповсюдження зловживання наркотиками та їх незаконного обігу постали в світі вже як глобальна загроза людству. На жаль, в Україні, яка є частиною глобалізаційних процесів, масштаби незаконного обігу наркотиків та наркоманії є критичними. Вже не один рік наркоманія в Україні має ознаки епідемії і належить до числа реальних і потенційних загроз національній безпеці України та стабільності в суспільстві. У наукових колах та суспільній свідомості поширеною є позиція, що ключовими засобами стримання масштабів наркоепідемії $\epsilon$ притягнення винних до кримінальної відповідальності за незаконні дії 3 ними за відповідними статтями розділу XIII Особливої частини Кримінального кодексу України (далі - КК України) та статтями 44, 106-1, 106-2 Кодексу України про адміністративні правопорушення (далі - КАП). Більш того, вже низка останніх редакцій проєктів нового КК України (починаючи 3 контрольного тексту від 25.07.2021 [1]) визнають кримінальними проступками незаконне виробництво, виготовлення, придбання, зберігання, наркотичних засобів та психотропних речовин у невеликих розмірах без мети збуту (у редакціях проєкту від 14 та 24 листопада 2021 року - без мети передачі [2, 3]). Зазначені діяння на сьогодні визнаються адміністративними правопорушеннями, передбаченими ст. 44 КАП. Можна бути впевненим у тому, що криміналізація зазначених діянь обумовлена бажанням якось стримати вже критичні масштаби поширення наркозлочинності та наркоманії в Україні. Проте, чи доцільним буде такий крок? Чи принесе він очікувані результати? Чи не отримаємо ми надмірну криміналізацію діянь у сфері незаконного обігу наркотичних засобів та психотропних речовин?

Аналіз останніх досліджень і публікацій. Проблематику кримінальної відповідальності за незаконне виробництво, виготовлення, придбання, зберігання, перевезення, пересилання чи збут наркотичних засобів, психотропних речовини або їх аналогів, кримінологічної характеристики та запобігання цим кримінальним правопорушенням плідно розробляли такі учені, як: Ю. В. Баулін, В. А. Бублейник, А. О. В’яземська, І. О. Доброрез, О. П. Горох, А. П. Закалюк, Т. А. Клименко, О. В. Козаченко, А. Ю. Мартинович, Н. А. Мирошниченко, А. А. Музика, О. В. Наден, В. М. Смітієнко, Є. В. Фесенко, Є. Л. Харківський, Н. В. Шепелєва тощо.

Проте ліберальні процеси, що відбуваються у низці країн Свропи та світу у сфері регулювання обігу деяких наркотичних засобів, масова поширеність серед населення України наркоманії, а отже і пов'язаних із нею незаконного виготовлення, виробництва, придбання, зберігання, перевезення, пересилання наркотичних засобів та психотропних речовин (ст. 44 КУПАП, ст. ст. 307, 309 КК України) обумовлюють актуальність дослідження питання щодо меж кримінально-правового реагування на незаконний обіг наркотичних засобів чи психотропних речовин у невеликих розмірах без мети збуту (передачі). 
Теоретичні засади криміналізації злочинів (кримінальних правопорушень) розроблялися в працях О. О. Дудорова, М. І. Хавронюка, П. Л. Фріса, Д. О. Балабанової, Г. А. Злобіна, В. М. Кудрявцева, О. І. Коробєєва, В. О. Навроцького, О. М. Готіна, М. І. Мельника, А. А. Митрофанова та інших науковців. Слід зазначити, що на сьогодні у вченні про криміналізацію питання про підстави, принципи, умови та приводи криміналізації, їх кількість та співвідношення між собою носять дискусійний характер, але відповідні дискусії «...точаться фактично не щодо суті правил криміналізації, а щодо їх систематизації (групування) та узагальнюючої назви таких вимог» [4, С. 52]. Так, наприклад, те, що О. О. Дудоров та Г. А. Злобін називають соціальними та соціально-психологічними принципами криміналізації [4, С. 52; 5, С. 208-227], Д. О. Балабанова - підставами криміналізації [6, С. 146-147]. Не вдаючись у теоретичні дискусії із зазначених питань, ми будемо працювати у межах того підходу у вченні про криміналізацію, згідно із яким підставою криміналізації діянь визнається відповідний ступінь і характер їхньої суспільної небезпеки [7, С. 66], а принципи криміналізації поділяються на дві основні групи: 1) соціальні і соціально-психологічні та 2) системно-правові і кримінальноправові) [4, С. 52; 5, С. 208-227].

Метою статті $\epsilon$ обгрунтування недоцільності криміналізації незаконного виробництва, виготовлення, придбання та зберігання наркотичних засобів чи психотропних речовин у невеликих розмірах без мети передачі (збуту) на підставі аналізу підстави та соціальних і соціально-психологічних принципів криміналізації діянь.

Виклад основного матеріалу. До соціальних і соціально-психологічних принципів науковці відносять принципи суспільної небезпеки, відносної поширеності діяння, пропорційності позитивних i негативних наслідків криміналізації та кримінально-політичної адекватності [4, С. 51]. У зв'язку із специфікою дослідження ми зосередимо свою увагу на підставі та соціальних і соціально-психологічних принципах криміналізації діянь. Адже системноправові принципи спрямовані на те, щоб запроваджені новели не погіршували якості кримінального законодавства, насамперед його системні характеристики.

У межах обраного нами підходу принцип суспільної небезпеки відповідає підставі криміналізації діянь: ступінь і характер суспільної небезпеки діяння, яке планується криміналізувати, має заподіювати об'єктам кримінальноправової охорони істотну (а не будь-яку іншу) шкоду [7, С. 66]. Першочергову роль у визначенні суспільної небезпеки незаконного виробництва, виготовлення, придбання та зберігання наркотичних засобів та психотропних речовин має характеристика правопорушника, який вчиняє зазначені дії. Адже, як слушно зазначає П. Л. Фріс, суспільна небезпечність $є$ характеристикою не лише певного діяння, а й особи, яка його вчиняє [8, С. 68].

Наказом Міністерства охорони здоров’я України від 01.08.2000 № 188 


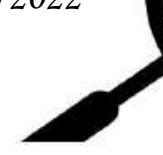

«Про затвердження таблиць невеликих, великих та особливо великих розмірів наркотичних засобів, психотропних речовин і прекурсорів, які знаходяться у незаконному обігу» [9] передбачено, що до невеликих розмірів віднесені ті наркотичні засоби та психотропні речовини, що не перевищують 10 визначених добових доз (definite daily dose) за даними Міжнародного комітету 3 контролю за наркотиками ООН. 3 огляду на це, а також враховуючи відсутність мети збуту (передачі), про яку йдеться у ст. 44 КАП та відповідній нормі проєкту КК України, можна із впевненістю стверджувати, що суб'єктами цих правопорушень виступають споживачі наркотичних засобів чи психотропних речовин та/або дрібні торговці у разі процесуальної недоведеності мети збуту (передачі) вилучених у них наркотичних засобів чи психотропних речовин. У структурі осіб, причетних до незаконного обігу наркотиків та психотропних речовин, вони характеризуються найменшою суспільною небезпечністю, особливо у порівнянні із учасниками та лідерами організованих форм наркозлочинності.

Крім того, не слід ігнорувати той факт, що певна частина споживачів та/ або дрібних торговців, про яких йде мова, є хворими на наркоманію, психологічно та фізично залежними від певних наркотичних засобів чи психотропних речовин. Отже розраховувати на те, що їх зупинить посилення юридичної відповідальності за придбання, зберігання чи перевезення цих засобів, у розмірі навіть однієї визначеної добової дози, не доводиться. Криміналізація зазначених діянь лише посилить психологічний тиск на них.

У структурі правопорушень у сфері незаконного обігу наркотичних засобів та психотропних речовин (ст. ст. 44, 106-1, 106-2 КАП, ст. ст. 305-320 КК України) суспільна небезпека незаконного виробництва, виготовлення, придбання та зберігання наркотичних засобів чи психотропних речовин у невеликих розмірах без мети збуту (передачі) також характеризується значно меншим ступенем та характером у порівнянні із суспільною небезпечністю незаконного збуту наркотичних засобів та психотропних речовин, а також їх незаконного виробництва, виготовлення, придбання, зберігання, перевезення, пересилання з метою збуту (ст. 307 КК України) та без мети збуту у розмірах, передбачених ст. 309 КК України.

Відповідно до принципу відносної поширеності діяння «...надмірна поширеність діяння, навіть якщо воно представляє суспільну небезпеку, є аргументом не за, а проти його криміналізації, хоча це і може здаватись дещо неочікуваним неспеціалісту» [5, С. 219]. На сьогодні, як вже зазначалось вище, масштаби незаконного обігу наркотиків та наркоманії в нашій державі $\epsilon$ критичними. За даними $\mathrm{MBC}$, в Україні офіційно нараховується близько 500 тис. наркоманів, із них понад 170 тис. регулярно вживають наркотики [10, С. 1]. За методикою оцінки латентності немедичного вживання наркотиків, розробленого Міністерством охорони здоров'я згідно 3 міжнародними рекомендаціями, в умовах України число зареєстрованих осіб з немедичним 
споживанням наркотиків має бути збільшено у 5 разів проти облікового [11, С. 32], і в останні роки має дорівнювати близько 2,5 мільйонів осіб. I всі ці особи на сьогодні є суб'єктами правопорушень, передбачених ст. 44 КАП та / або ст. 309 КК України. Як не прикро це усвідомлювати, але наведені цифри дають підстави говорити вже про надмірну їх поширеність. Маємо визнати, що правоохоронні органи не в змозі притягнути до кримінальної відповідальності таку масу людей за діяння, пов’язані зі споживанням наркотичних засобів. I на сьогодні можна стверджувати, що ст. 309 КК України застосовується вибірково, принцип невідворотності покарання реалізується далеко не завжди. Перетворення адміністративного правопорушення, передбаченого ст. 44 КАП, у кримінальний проступок, лише посилить означену тенденцію. Безкарною буде залишатись ще більша кількість діянь, оголошених кримінально протиправними. Хіба такий стан речей здатен утримати більш менш велику кількість наших громадян від вживання наркотичних засобів та психотропних речовин? Хіба масова безкарність нового кримінального проступку підвищить авторитет правоохоронних органів і держави у цілому?

3 такими питаннями ми переходимо до наступного принципу криміналізації діянь - принципу пропорційності позитивних і негативних наслідків криміналізації діянь. Зміст його полягає у тому, що встановлення кримінальної караності діяння припустиме лише тоді, коли ми впевнені, що позитивні соціальні результати застосування кримінального права істотним чином перевищать неминучі негативні наслідки криміналізації [5, С. 219].

Щоб спрогнозувати можливі наслідки криміналізації адміністративного правопорушення, передбаченого ст. 44 КАП, проаналізуємо статистичні дані про кількість облікованих діянь, кваліфікованих за ст. ст. 307 та 309 КК України, та кількість кримінальних проваджень, скерованих до суду із обвинувальним актом за цими статтями [12].

Після набуття чинності новим Кримінальним процесуальним кодексом наприкінці 2012 року у наступні 2013-2015 роки співвідношення облікованих злочинів, передбачених ст. ст. 307 та 309 КК України, складало майже 1:2 відповідно (у середньому по 8152 та 16766 злочини відповідно). У 2016 році кількість облікованих за ст. 309 КК України злочинів перевищила аналогічний показник за ст. 307 КК України у 7,6 разів (17398 та 2293 злочини відповідно). Це пояснюється процесом активного становлення новоствореної Національної поліції і тому для коректності аналізу не будемо брати до уваги показники 2016 року. У 2017-2018 роках співвідношення облікованих ст. ст. 307 та 309 КК України складало майже 1:4 (у середньому по 5241 та 19047 злочинів відповідно), у 2019 році - 1:3 (6165 та 18483 злочини відповідно), у 2020 році 1:2 (8150 та 15735 кримінальних правопорушень відповідно).

Співвідношення кримінальних проваджень, направлених до суду 3 обвинувальним актом, за ст. ст. 307 та 309 КК України у 2013-2015 роках також складало приблизно 1:2 (у середньому по 5454 та 13028 проваджень 
відповідно). У 2016 році кримінальних проваджень за ст. 307 КК України було направлено у 15 разів менше, ніж за ст. 309 КК України (634 та 9726 злочинів відповідно), але, як вже зазначалось, не будемо враховувати показники цього року. У 2017-2018 роках співвідношення кримінальних проваджень за злочинами, передбаченими ст. ст. 307 та 309 КК України, складало 1:5 (у середньому по 2608 та 12615 проваджень відповідно), у 2019 році - майже 1:3 (3236 та 11217 проваджень відповідно), у 2020 році - 1:2 (4838 та 9707 проваджень відповідно).

Отже, ми бачимо, що ресурси правоохоронних органів у справі протидії злочинності не є безмежними. Збільшення кількості облікованих кримінальних правопорушень, а також скерованих до суду 3 обвинувальним актом кримінальних проваджень за ст. 307 КК України здійснюється за рахунок зменшення кількості аналогічних показників за ст. 309 КК України. Перетворення незаконного виробництва, виготовлення, придбання та зберігання наркотичних засобів чи психотропних речовин у кримінальний проступок буде вимагати від правоохоронних органів збільшення кількості кадрових, організаційних та матеріальних ресурсів на здійснення досудового розслідування у формі дізнання у порівнянні із ресурсами, необхідними для адміністративного провадження. Витрати держави i суспільства на розслідування фактів придбання, зберігання, перевезення, скажімо, канабісу до 5 грамів або екстракційного опію до 0,5 грамів психічно і фізично залежними від цих засобів особами зростуть непропорційно до можливого позитивного ефекту у вигляді загальної превенції наркоманії. Немає впевненості у тому, що зростання витрат на боротьбу із споживачами та дрібними торговцями наркотиками чи психотропними речовинами не буде здійснюватися за рахунок економії ресурсів на протидію більш суспільно небезпечним проявам наркозлочинності або інші суспільно корисні цілі.

Принцип кримінально-політичної адекватності полягає у тому, що зміст кожної кримінально-правової новели так чи інакше має відбивати загальні напрямки державної кримінальної політики [5, С. 224]. Слід зазначити, що криміналізація діянь, передбачених ст. 44 КАП, суперечить меті, завданням та принципам чинної ще Стратегії державної політики щодо наркотиків на період до 2020 року [13], а також проєкту Стратегії державної політики щодо наркотиків на період до 2030 року [14]. Обидва документа визнають необхідним переорієнтацію заходів протидії незаконному обігу наркотичних засобів та психотропних речовин від кримінально-караних до адміністративновиправних, біопсихосоціальних та профілактичних.

Висновки. Таким чином, доходимо висновку, що криміналізація незаконного виробництва, виготовлення, придбання та зберігання наркотичних засобів чи психотропних речовин у невеликих розмірах без мети передачі (збуту) на сьогоднішній день, на жаль, суперечить соціальним та соціальнопсихологічним принципам криміналізації діянь з наступних причин. 1. Ці дії є 
найменш суспільно небезпечним у порівнянні із аналогічними діями, передбаченими ст. ст. 307, 309 КК України. 2. Занадто велика поширеність наркоманії (а значить, і незаконного виробництва, виготовлення, придбання та зберігання наркотичних засобів чи психотропних речовин у невеликих розмірах без мети збуту (передачі) виходить за межі практичних можливостей кримінальної юстиції. 3. Існує ризик, що криміналізація цих діянь призведе до того, що зусилля правоохоронних органів будуть спрямованими на боротьбу із ними за рахунок економії кадрових, матеріально-технічних, організаційних ресурсів на інші суспільно корисні цілі та протидію більш суспільно небезпечним проявам наркозлочинності. Негативні соціальні наслідки криміналізації адміністративного правопорушення, передбаченого ст. 44 КАП, перевищать очікуваний позитивний результат у вигляді зменшення попиту на наркотики та психотропні речовини. 4. Криміналізація незаконного виробництва, виготовлення, придбання та зберігання наркотичних засобів чи психотропних речовин у невеликих розмірах без мети передачі (збуту) суперечить державній політиці щодо наркотиків.

На підставі викладеного пропонується залишити незаконне виробництво, виготовлення, придбання та зберігання наркотичних засобів чи психотропних речовин у невеликих розмірах без мети передачі адміністративними правопорушеннями i не перетворювати їх на кримінальні проступки. Ефективність протидії наркоманії та наркозлочинності має бути підвищена за рахунок не посилення репресивних заходів щодо споживачів наркотиків та психотропних речовин, а вдосконалення профілактичної роботи 3 ними та групами ризику, послаблення чинників наркоманії, системного наступального характеру боротьби із організованими злочинними угрупованнями у сфері наркобізнесу.

\section{Лimepamypa:}

1. Кримінальний кодекс (проєкт) : контрольний текст станом на 25.07.2021. URL: https://newcriminalcode.org.ua/upload/media/2021/08/12/1-kontrolnyj-tekstproektu-kk-25-07-2021-1.pdf (дата звернення: 22.11.2021).

2. Кримінальний кодекс (проєкт) : контрольний текст станом на 14.11.2021. URL: https://newcriminalcode.org.ua/upload/media/2021/11/15/1-kontrolnyj-tekst-proektu-kk-14-112021-oznaky.pdf (дата звернення: 22.11.2021).

3. Кримінальний кодекс (проєкт) : контрольний текст станом на 24.11.2021. URL: https://newcriminalcode.org.ua/upload/media/2021/11/25/kontrolnyj-proekt-kk24-11-2021.pdf (дата звернення: 29.11.2021).

4. Дудоров О. О. Кримінальне право: теорія і практика (вибрані праці). Київ : Ваїте, 2017. С. 51-54.

5. Кудрявцев В. Н., Дагель П. С., Злобин Г. А., Келина С. Г. [и др.] Отв. ред. Кудрявцев B. Н., Яковлев А. М. Основания уголовно-правового запрета: криминализация и декриминализация. Москва : Наука, 1982. 304 c. URL: https://uallib.org/book/ 3210602/697828? $\mathrm{id}=3210602 \&$ secret=697828. (дата звернення: 22.11.2021).

6. Балабанова Д. О. Загальні засади теорії криміналізації. Актуальні проблеми держави і права. 2009. Вип. 47. С. 145-148. 


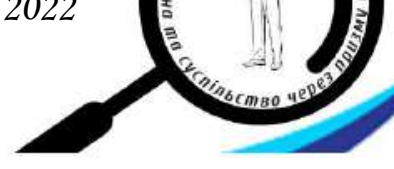

7. Дудоров О.О., Хавронюк М.І. Кримінальне право : навчальний посібник / За заг. ред. М.І. Хавронюка. Київ : Ваіте, 2014. 944 с.

8. Правова доктрина України : у 5 т. Т. 5. Кримінально-правові науки в Україні: стан, проблеми та шляхи розвитку. За заг. ред. В. Я. Тація, В. І. Борисова; В. О. Навроцький, В. О. Туляков, М. І. Колос та ін. Харків : Право, 2013. 1240 с.

9. Про затвердження таблиць невеликих, великих та особливо великих розмірів наркотичних засобів, психотропних речовин і прекурсорів, які знаходяться у незаконному обігу: Наказ Міністерства охорони здоров'я України від 01.08.2000 p. № 188. URL: https://zakon.rada.gov.ua/laws/show/z0512-00\#Text. (дата звернення: 22.11.2021).

10. Мокляк С. В. Кримінально-правова характеристика незаконного виробництва, виготовлення, придбання, зберігання, перевезення, пересилання чи збуту наркотичних засобів, психотропних речовин або їх аналогів, що вчиняються організованою групою : автореф. дис. ... канд. юрид. наук : 12.00.08. Нац. акад. прав. наук України, НДІ вивч. проблем злочинності ім. В. В. Сташиса. Харків, 2018. 20 с.

11. Наркозлочинність: кримінологічна характеристика та запобігання : наук.-навч. посібник / Інстит. вивч. пробл. злочинності АПрН України; за ред. А. П. Закалюка; А. А. Бова, В. І. Женунтій, А. П. Закалюк, О. Г. Кулик та ін.; передм. А. П. Закалюка. Київ, 2006. $294 \mathrm{c}$.

12. Статистична інформація про стан злочинності та результати прокурорсько-слідчої діяльності / Генеральна прокуратура України : офіц. веб-сайт URL: https://www.gp.gov.ua/ ua/statinfo.html. (дата звернення: 10.10.2021).

13. Стратегія державної політики щодо наркотиків на період до 2020 року: Розпорядження Кабінету Міністрів України від 28.08.2013 № 735-p. URL: http://zakon.rada.gov.ua/laws/show/735-2013-\%D1\%80\#n8. (дата звернення: 10.10.2021).

14. Стратегія державної політики щодо наркотиків на період до 2030 року : проєкт Розпорядження Кабінету Міністрів України. URL: https://moz.gov.ua/uploads/ckeditor/\% D0\%93\%D1\%80\%D0\%BE\%D0\%BC\%D0\%B0\%D0\%B4\%D1\%81\%D1\%8C\%D0\%BA\%D0\%B5 $\% 20 \% \mathrm{D} 0 \% \mathrm{BE} \% \mathrm{D} 0 \% \mathrm{~B} 1 \% \mathrm{D} 0 \% \mathrm{~B} 3 \% \mathrm{D} 0 \% \mathrm{BE} \% \mathrm{D} 0 \% \mathrm{~B} 2 \% \mathrm{D} 0 \% \mathrm{BE} \% \mathrm{D} 1 \% 80 \% \mathrm{D} 0 \% \mathrm{~B} 5 \% \mathrm{D} 0 \% \mathrm{BD} \%$ D0\%BD\%D1\%8F/2021/05/18/\%D0\%A1\%D1\%82\%D1\%80\%D0\%B0\%D1\%82\%D0\%B5\%D0\% B3\%D1\%96\%D1\%8F.pdf. (дата звернення: 10.10.2021).

\section{References:}

1. Kryminalnyi kodeks (proiekt). [Criminal Code (draft)]. Kontrolnyi tekst stanom na 25.07.2021. URL: https://newcriminalcode.org.ua/upload/media/2021/08/12/1kontrolnyj-tekst-proektu-kk-25-07-2021-1.pdf. [in Ukrainian].

2. Kryminalnyi kodeks (proiekt). [Criminal Code (draft)]. Kontrolnyi tekst stanom na 14.11.2021. URL: https://newcriminalcode.org.ua/upload/media/2021/11/15/1kontrolnyj-tekst-proektu-kk-14-11-2021-oznaky.pdf. [in Ukrainian].

3. Kryminalnyi kodeks (proiekt). [Criminal Code (draft)]. Kontrolnyi tekst stanom na 24.11.2021. URL: https://newcriminalcode.org.ua/upload/media/2021/11/25/kontrolnyjproekt-kk-24-11-2021.pdf. [in Ukrainian].

4. Dudorov, O. O. (2017) Kryminalne pravo: teoriia i praktyka (vybrani pratsi). [Criminal law: theory and practice (selected works)]. Kyiv: Vaite. [in Ukrainian].

5. Kudriavtsev, V. M., Dahel, P. S., Zlobyn, H. A., Kelyna, S. H. (1982) Osnovaniya ugolovno-pravovogo zapreta: kriminalizatsiya i dekriminalizatsiya. [Grounds for criminal prohibition: criminalization and decriminalization] Moskva: Nauka. [in Russian].

6. Balabanova, D. O. Zahalni zasady teorii kryminalizatsii [General principles of the theory of criminalization]. Aktualni problemy derzhavy i prava - Actual Problems of State and Law, issue 47, 145-148. [in Ukrainian]. 
7. Dudorov, O. O., Khavroniuk, M. I. (2014). Kryminalne pravo [Criminal law]. Kyiv: Vaite. [in Ukrainian].

8. Pravova doktryna Ukrayiny. Kryminalno-pravovi nauky v Ukraini: stan, problemy ta shliachy rozvytku. (2013) [Criminal science in Ukraine: state, problems and ways of development]. (Vol. 1-5; Vol. 5). Borisov, V. I., Tatsii, V. Ya. (Eds.). Kharkiv: Pravo. [in Ukrainian].

9. Nakaz Ministerstva okhrany zdorovia Ukrainy Pro zatverdzhennia tablyts nevelykykh, velykykh ta osoblyvo velykykh rozmiriv narkotychnykh zasobiv, psykhotropnykh rechovyn i prekursoriv, yaki znakhodiatsia u nezakonnomu obigu : pryynyatyy 01.08.2000 № 188 [The Order of the Ministry of Health of Ukraine «On approval of tables of small, large and especially large sizes of narcotic drugs, psychotropic substances and precursors who are in illegal circulation»]. URL: https://zakon.rada.gov.ua/laws/show/z0512-00\#Text. [in Ukrainian].

10. Mokliak, S.V. (2018). Kryminalno-pravova kharakterystyka nezakonnogo vyrobnytstva, vygotovlennia, prydbannia, zberigannia, perevezennia, peresylannia chy zbutu narkotychnykh zasobiv, psykhotropnykh rechovyn abo yikh analogiv, shcho vchyniaiutsia organizovanoiu grupoiu. (Extended abstract of candidate's thesis). National Academy of Legal Sciences of Ukraine, Academician Stashis Scientific Research Institute for the Study of Crime Problems National Academy of Law Sciences of Ukraine. Kharkiv.

11. Narkozlochynnist: kryminologichna kharakterystyka ta zapobigannia [Drug Crime: Criminological Characteristics and Prevention] (2006) Bova, A. A., Zhenuntii, V. I., Zakaliuk, A. P., Kulik, O. H. et al. A. P. Zakaliuk (Ed.). Kyiv: Yurinkom Inter. [in Ukrainian].

12. Statystychna informatsiia pro stan zlochynnosti ta rezultaty prokurorsko-slidchoi diialnosti : ofitsiinyi veb-sait Heneralnoi prokuratury Ukrainy. URL: https://www.gp.gov.ua/ua/ statinfo.html. [in Ukrainian].

13. Rozporiadzhennia Kabinetu Ministriv Ukrainy «Pro skhvalennya Strategii derzhavnoi polityky shchodo narkotykiv na period do 2020 roku» : pryynyate 28.08.2013 r. № 735-r. [Order of the Cabinet of Ministers of Ukraine «On approval of the Strategy of the state policy on drugs for the period till 2020 roku»]. URL: http://zakon.rada.gov.ua/laws/show/735-2013-\%D1\%80\#n8. [in Ukrainian].

14.Strategiia derzhavnoi polityky shchodo narkotykiv na period do 2030 roku : proiekt rozporiadzhennia Kabinetu Ministriv Ukrainy [Draft Order of the Cabinet of Ministers of Ukraine «On approval of the Strategy of the state policy on drugs for the period till 2030»]. URL: https://moz.gov.ua/uploads/ckeditor/\%D0\%93\%D1\%80\%D0\%BE\%D0\%BC\%D0\%B0\%D0\%B4 $\% \mathrm{D} 1 \% 81 \% \mathrm{D} 1 \% 8 \mathrm{C} \% \mathrm{D} 0 \% \mathrm{BA} \% \mathrm{D} 0 \% \mathrm{~B} 5 \% 20 \% \mathrm{D} 0 \% \mathrm{BE} \% \mathrm{D} 0 \% \mathrm{~B} 1 \% \mathrm{D} 0 \% \mathrm{~B} 3 \% \mathrm{D} 0 \% \mathrm{BE} \% \mathrm{D} 0 \% \mathrm{~B} 2 \% \mathrm{D} 0$ \%BE\%D1\%80\%D0\%B5\%D0\%BD\%D0\%BD\%D1\%8F/2021/05/18/\%D0\%A1\%D1\%82\%D1\%80\%D 0\%B0\%D1\%82\%D0\%B5\%D0\%B3\%D1\%96\%D1\%8F.pdf. [in Ukrainian]. 